\title{
Evaluation of Orally Administered Anthelmintic Treatment Options for Dentostomella translucida in Naturally Infected Mongolian Gerbils (Meriones unguiculatus)
}

\author{
Doğal Enfekte Mongolian Gerbillerde (Meriones unguiculatus) \\ Dentostomella translucida Tedavisinde Oral Olarak Uygulanan \\ Antelmintik Seçeneklerinin Değerlendirilmesi
}

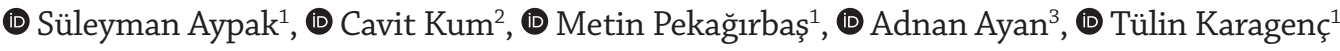 \\ ${ }^{1}$ Aydın Adnan Menderes University Veterinary Faculty, Department of Parasitology, Aydın, Turkey \\ ${ }^{2}$ Aydın Adnan Menderes University Veterinary Faculty, Department of Pharmacology, Aydın Turkey \\ ${ }^{3}$ Van Yüzüncü Yll University Veterinary Faculty, Department of Genetic, Van, Turkey
}

Cite this article as: Aypak S, Kum C, Pekağırbaş M, Ayan A, Karagenç T. Evaluation of Orally Administered Anthelmintic

Treatment Options for Dentostomella translucida in Naturally Infected Mongolian Gerbils (Meriones unguiculatus)

Turkiye Parazitol Derg 2021;45(1):17-21

\begin{abstract}
Objective: This study aimed to evaluate the efficacy of eprinomectin, moxidectin and fenbendazole for treating Dentostomella translucida infections in naturally infected Mongolian gerbils (Meriones unguiculatus).

Methods: A total of 28 gerbils were placed in individually numbered cages to determine the individual animal parasite load. Eggs per gram (EPG) counts were used to estimate the efficacy of the drugs. The day before the anthelmintic administration was denoted as day 0 , and the EPG counts were determined by the McMaster technique from the stool removed from the cage bottom on days 7, 14, 21 and 28. The animals were assigned to one of four treatment groups according to their day 0 EPG counts. The orally administered drugs in the treatment groups were eprinomectin $(15 \mathrm{mg} / \mathrm{kg})$, moxidectin $(0.4 \mathrm{mg} / \mathrm{kg})$ and fenbendazole (12 $\mathrm{mg} / \mathrm{kg}$ ) for groups 1-3, respectively. The fourth group served as the control (without any drug administration).

Results: Treatment efficacy was evaluated based on weekly EPG counts. The values decreased to zero in the fenbendazole group at 4 weeks of follow-up after treatment, and no parasite was found in any of the repeated examinations. The eprinomectin and moxidectin groups exhibited a fluctuating EPG state on both individual and group basis.

Conclusion: $D$. translucida, which is known as the specific parasite of gerbils, can easily affect other members of the animal colony; thus, the control of its presence in gerbil breeding units is necessary. Therefore, the reported effective drug treatments are important for the fight against the investigated parasitic infection.
\end{abstract}

Keywords: Anthelmintics, Dentostomella translucida, Mongolian gerbil, nematoda

Öz

Amaç: Dentostomella translucida ile doğal enfekte Mongolian gerbillerin (Meriones unguiculatus) tedavisinde kullanılan eprinomektin, moksidectin ve fenbandazolün tedavideki etkinliğinin değerlendirilmesi amaçlanmıştır.

Yöntemler: Bireysel parazit yüklerini belirlemek için, 28 gerbil ayrı ayrı numaralandırılmış kafeslere konulmuştur. İlaç etkinliğini belirlemek için gram dışkıdaki yumurta sayısı (EPG) hesaplanmıştır. Antelmentik uygulamasından önceki gün 0. gün olarak kaydedilmiş ve gram dışkıdaki yumurta miktarı, 7, 14, 21 ve 28. günlerde kafeslerden alınan dışkı örneğine uygulanan McMaster tekniği ile tespit edilmiştir. Hayvanlar 0. günde tespit edilen EPG sayılarına göre oluşturulan dört tedavi grubundan birine kaydedilmiştir. Eprinomektin (15 mg/kg), moksidektin $(0,4 \mathrm{mg} / \mathrm{kg})$ ve fenbendazol $(12 \mathrm{mg} / \mathrm{kg})$ oral olarak üç gruba uygulanmış, dördüncü grup ise herhangi bir ilaç uygulanmayan kontrol grubu olarak belirlenmiştir.

Bulgular: Uygulanan tedavinin etkinliği haftalık EPG sayılarına göre değerlendirilmiştir. Tedaviden sonraki dört takip haftasında, fenbendazol uygulanan grubun EPG değerinin sıfıra düştüğü ve tekrar edilen dışkı muayenelerinde parazite

Received/Geliş Tarihi: 29.05.2020 Accepted/Kabul Tarihi: 16.08.2020

Address for Correspondence/Yazışma Adresi: Metin Pekağırbaş, Aydın Adnan Menderes University Veterinary Faculty, Department of Parasitology, Aydın, Turkey

Phone/Tel.: +90 2562470700 E-mail/E-posta: metinpekagirbas@gmail.com ORCID ID: orcid.org/0000-0003-3170-410X

${ }^{\circ}$ Copyright 2021 Turkish Society for Parasitology - Available online at www.turkiyeparazitolderg.org

(c) Telif hakkı 2021 Türkiye Parazitoloji Derneği - Makale metnine www.turkiyeparazitolderg.org web sayfasından ulașılabilir. 
rastlanmadığı belirlenmiştir. Eprinomektin ve moksidektin gruplarında ise hem bireysel, hem de grup bazında EPG sayılarının dalgalanma gösterdiği gözlenmiştir.

Sonuç: Gerbillerin spesifik parazitleri olarak bilinen $D$. translucida, özellikle deney hayvanları üretim ve yetiştirme birimlerinde varlığı kontrol gerektiren ve hayvan kolonisinin diğer üyelerini kolayca etkileyebilen bir parazittir. Bu nedenle, çalışmada bildirilen etkili ilaç tedavisi bu parazitlere karşı mücadelede önem taşımaktadir.

Anahtar Kelimeler: Antelmintik, Dentostomella translucida, Mongolian gerbil, nematoda

\section{INTRODUCTION}

The popularity and use of the Mongolian gerbil (Meriones unguiculatus) in research continues to increase. While widely known as experimental animals, in recent years they have also become more popular as pets. There are 10 breeds and more than 100 types in the subfamily Gerbillinae. American and Japanese researchers were to use the species $M$. unguiculatus for the first time as lab animals because of their high reproductive abilities, gentle demeanor, and relative resistance to disease (1).

Dentostomella translucida, an oxyurid nematode also known as a threadworm, is the most common nematode found in these animals (1-3). This parasite has also been detected in the Great gerbil (Rhombomys opimus) (1) in the Golden hamster (Mesocricetus auratus (4), and in the African giant rat (Cricetomys gambianus) (5), in addition to the Mongolian gerbil. The parasite develops directly without an intermediate host. The eggs develop between 25 and 29 days and become infective at 5 to 8 days when taken orally (6). While parasites were reported to be present in the small intestine, they have also been detected in the stomach and large intestine $(1,7-10)$. As is the case with many pinworm infections in rodents, there are usually no symptoms even in severe infections due to D. translucida $(1,6,11)$. The life cycle, pathogenicity, and zoonotic potential of this nematode have not been fully established. Eggs are discarded with stool pellets as in Aspiculuris tetraptera and stool flotation techniques are typically used to detect infection $(1,2,6,11)$.

Anthelmintics such as piperazine, macrocyclic lactone, and benzimidazole compounds are widely used in the treatment of threadworms in rodents. Specific agents against different breeds or species of threadworms have been used individually or in combination $(1,6,12)$. These drugs have a broad spectrum and a reasonably safe dose range (13). Fenbendazole is notable due to their ovicidal activity because they make the fight for the threadworms more difficult due to their contamination of the surroundings and eggs (14). It has been shown that various macrocyclic lactone compounds have been effective in treating some parasites in rodents (15) and ineffective in others (16). Moxidectin and eprinomectin belong to the avermectins anthelmintic group based upon their chemical structures (17) Differences in drug makeup can account for differences in their effectiveness against parasites. This variation in effect was seen in anthelmintic experiments conducted using different rodents and threadworms (6). As such, there is a need for continued research into treatment of threadworms in rodents, taking into account drug options and variations.

The health of experimental animals is important because diseased animals may confound study results. In rodents, threadworms have the potential to contaminate the environment and infect the entire colony in a short time, making eradication important (1). In this study, we aimed to evaluate the efficacy of eprinomectin, moxidectin, and fenbendazole in the treatment of $D$. translucida in gerbils (M. unguiculatus).

\section{METHODS}

\section{Animals}

This study was approved by Aydın Adnan Menderes University Animal Experiment Ethics Committee dated 28/9/2017 in accordance with decision number 64583101/2017/106. As the study was conducted on experimental animals, patient approval was not required.

Dentostomella translucida were found in the small intestines of a gerbil in the experimental animal production and research center of the Aydin Adnan Menderes University Veterinary Faculty, during a necropsy conducted to determine the cause of death. Fecal samples were examined to determine the possibility that others might have been affected. $D$. translucida eggs were found in stool samples from 28 gerbils. No clinical signs of disease were observed in these animals. Oral anthelmintic treatments were planned for those gerbils in which the parasites were detected.

\section{Determination of Individual Parasitic Load}

The gerbils were housed in numbered clean individual cages during the study and provided water and feed ad libitum. The animals were grouped based on eggs per gram (EPG) in their feces on day 0. Care was taken to ensure that the initial group averages were close to each other in terms of EPG values when setting up the treatment groups. In previous studies, the flotation method preferred rather than the anal tape method for determining $D$. translucida infections $(1,2)$. We also used the stool flotation technique. EPG were counted to determine drug efficacy. Due to intermittent egg-laying by the parasite, treatment efficacy monitoring was conducted over a one-month period at one-week intervals $(1,11)$. The day before anthelmintic administration was considered as day 0 and EPG were determined by the McMaster technique with salt water (18) on days 7, 14, 21, and 28. On the days specified for EPG determination, the stool collected from the cage floors was transported to the laboratory in appropriate numbered containers. Treatment effectiveness was then evaluated based upon the number of eggs detected.

\section{Anthelmintic Application and Evaluation}

Based upon individual animal EPG on day 0, the gerbils were divided into four similarly infected groups, three treated and one control. The treatments of either eprinomectin-Eprecis ${ }^{\circledR}$ (CEVA, Turkey) (15 mg/kg), moxidectin-Cydectin ${ }^{\circledR}$ (Zoetis, USA) $(0.4 \mathrm{mg} / \mathrm{kg})$, or fenbendazole-Panacur oral paste $(12 \mathrm{mg} /$ $\mathrm{kg}$ ) were administered by a single oral gavage dose based upon individual animal weight. Preferred drugs in the study were used at appropriate dosage ranges as noted by Şanlı (17).

\section{Evaluation of the Treatment Results}

After following drug administration, the groups were monitored for 4 weeks $(7,14,21$, and 28 days) for individual and group egg counts and the proportion of individual animals that were 
egg-positive within each group. Drug efficacy outcomes were calculated. At the end of the study the control group as well as the untreated groups were treated with the anthelmintic that was monitored to be effective.

\section{RESULTS}

EPG values decreased to zero in the fenbendazole group in the four follow-up weeks after the treatment and no parasites were found in any repeat examinations (Table 1). Parasites generally persisted for four weeks with fluctuating EPG values both individually and as a group in the eprinomectin and moxidectin treated groups (Figure 1). At the end of the study, infected animals from the control group, as well as the treated groups, were provided with the anthelmintic that was determined to be most effective.

\section{DISCUSSION}

Even though oxyurids are generally considered to be relatively non-pathogenic in rodents, it is thought that they might be related to decreased growth rates associated with severe infections, diarrhea, intestinal prolapse, rectal prolapse, intestinal

\begin{tabular}{|c|c|c|c|c|c|c|}
\hline Groups & Gerbil no & Day 0 & Day 7 & Day 14 & Day 21 & Day 28 \\
\hline \multirow{9}{*}{ Moxidectine } & G12 & 17,000 & 1.600 & 800 & 400 & 6.000 \\
\hline & G1 & 7.600 & 0 & 13,000 & 0 & 0 \\
\hline & G16 & 4.200 & 2.600 & 0 & 0 & 8.000 \\
\hline & G6 & 3.000 & 1.400 & 800 & 1.600 & 400 \\
\hline & G17 & 2.400 & 600 & 400 & 400 & 2.000 \\
\hline & G9 & 1.800 & 0 & 0 & 3.600 & 0 \\
\hline & G10 & 1.000 & 800 & 0 & 0 & 1.200 \\
\hline & *GTEC & 37,000 & 7.000 & 15,000 & 6.000 & 17,600 \\
\hline & ${ }^{* *}$ EPI (\%) & 100 & 71 & 57 & 57 & 71 \\
\hline \multirow{9}{*}{ Eprinomectine } & G14 & 16,400 & 400 & 0 & 400 & 0 \\
\hline & G15 & 7.200 & 1.200 & 0 & 3.600 & 4.000 \\
\hline & G22 & 4.400 & 0 & 0 & 0 & 0 \\
\hline & G13 & 4.000 & 2.200 & 0 & 2.000 & 0 \\
\hline & G2 & 3.600 & 0 & 800 & 0 & 0 \\
\hline & G5 & 3.200 & 0 & 2.200 & 3.200 & 1.600 \\
\hline & G8 & 800 & 600 & 19,200 & 0 & 4.800 \\
\hline & ${ }^{*}$ GTEC & 39,600 & 4.400 & 22,200 & 9.200 & 10,400 \\
\hline & **EPI (\%) & 100 & 57 & 43 & 57 & 43 \\
\hline \multirow{9}{*}{ Fenbendazole } & G21 & 6.600 & 0 & 0 & 0 & 0 \\
\hline & G24 & 5.200 & 0 & 0 & 0 & 0 \\
\hline & G11 & 4.400 & 0 & 0 & 0 & 0 \\
\hline & G20 & 2.400 & 0 & 0 & 0 & 0 \\
\hline & G23 & 800 & 0 & 0 & 0 & 0 \\
\hline & G18 & 400 & 0 & 0 & 0 & 0 \\
\hline & G4 & 400 & 0 & 0 & 0 & 0 \\
\hline & *GTEC & 20,200 & 0 & $\mathbf{0}$ & o & $\mathbf{0}$ \\
\hline & ${ }^{* *}$ EPI (\%) & 100 & $\mathbf{0}$ & 0 & $\mathbf{0}$ & $\mathbf{0}$ \\
\hline \multirow{9}{*}{ Control } & G7 & 4.800 & 5.600 & 3.600 & 3.200 & 3.600 \\
\hline & G19 & 500 & 1.600 & 6.800 & 8.000 & 1.200 \\
\hline & G25 & 1.760 & 2.000 & 0 & 3.600 & 6.400 \\
\hline & G26 & 5.000 & 8.400 & 9.200 & 6.000 & 7.600 \\
\hline & G27 & 800 & 1.600 & 1.600 & 1.200 & 400 \\
\hline & G3 & 6.200 & 6.800 & 7.800 & 3.200 & 3.200 \\
\hline & G28 & 1.200 & 800 & 400 & 1.600 & 800 \\
\hline & ${ }^{*}$ GTEC & 20,260 & 26,800 & 29,400 & 26,800 & 23,200 \\
\hline & **EPI (\%) & 100 & 100 & 86 & 100 & 100 \\
\hline
\end{tabular}




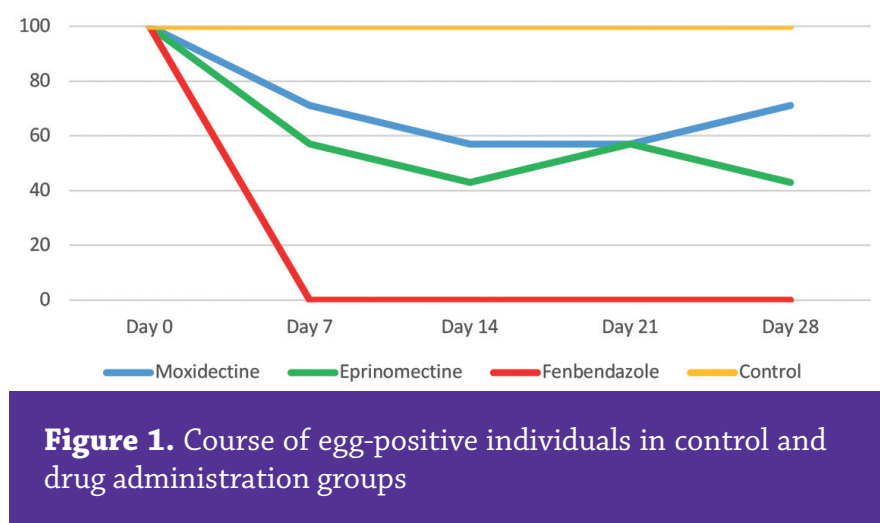

obstruction, and mucoid enteritis $(5,19)$. Due to the intermittent egg-laying pattern of the parasite (2) evaluation in the groups in which the drug efficacy was not very strong became difficult. It was observed that some individual EPG values which had decreased to zero went up by the next evaluation. For these reasons, individual and group total EPG values were considered. The eprinomectin and moxidectin treated groups showed a decrease in egg-positive individuals and total group EPG values; however, a net efficiency ratio could not be established due to fluctuations in the group and individual values. The rate of parasitic individual animals dropped to $43 \%$ for eprinomectin and $57 \%$ for moxidectin; however, these rates did not persist. As a result, eprinomectin and moxidectin, which we know to be effective in the treatment of many nematodes, did not show complete efficacy against $D$. translucida in this study.

Successful results were reportedly obtained with avermectins against threadworms in other rodents (6). Wilkerson et al. (1) reported in their trials with piperazine and ivermectin in gerbils against the same parasite that during the first, fourth, and eighth week the parasite maintained its presence at $60 \%$ (piperazine) and $50 \%$ (ivermectin) respectively. In the same study, fenbendazole activity alone and in combination with ivermectin was also tested. Fenbendazole alone showed $100 \%$ activity from the first week onwards and the combination treatment showed a $100 \%$ effectivity from the fourth to the eighth weeks with the presence of parasites reduced to zero. Approximately half of the administered fenbendazole is excreted in the stool (13) facilitating the direct and intense demonstration of drug activity on the parasites in the intestine. When the ovicidal activity of the benzimidazole group is added, the active substance becomes a good eradication agent for parasites that enter its spectrum of action. In our study, full activity was monitored in the fenbendazole group starting from the first week and continuing through the fourth week, proving it can be used as an effective option in the elimination of $D$. translucida. The presence of $D$. translucida in Mongolian gerbils in Mexico (19) Poland, Kazakhstan, Turkmenistan, Uzbekistan (3), Colombia (8), Brazil (20), Bulgaria (21) and Iran (9) has been stated in various studies. In Turkey, Burgu (7) and Ayan (10) detected D. translucida in a naturally infected gerbil. The fact that this parasite, which is very common in gerbils around the world, was only encountered for the second time in Turkey, can be explained by the fact that these animals are not used widely there and hence their parasites have been ignored. In comparison to other threadworms eggs that stick to the anal region in rodents, the eggs of $D$. translucida settle particularly in the stomach and small intestines and are excreted in stool pellets $(6,11)$. The spread of eggs stuck to the anal region occurs in a much shorter time than those excreted with stool pellets. Effective drug administration and the regular removal of feces can reduce the probability of recurrent infections and make eradication of $D$. translucida much easier than other threadworms.

\section{CONCLUSION}

Although the potential for transmission to humans and the effects on experimental animal physiology of this parasite is not yet known, it is always preferred that pet and test animals be free from parasites. D. translucida, which is known as a specific parasite of gerbils, can easily affect other members of the animal colony if no measures are taken, thus, control of its presence in gerbil breeding units is essential.

\section{* Ethics}

Ethics Committee Approval: This study was approved by Aydın Adnan Menderes University Animal Experiment Ethics Committee dated 28/9/2017 in accordance with decision number 64583101/2017/106

Informed Consent: As the study was conducted on experimental animals, patient approval was not required.

Peer-review: Internally peer-reviewed.

\section{* Authorship Contributions}

Surgical and Medical Practices: S.A., C.K., M.P., A.A., T.K., Concept: S.A., C.K., M.P., A.A., T.K., Design: S.A., C.K., M.P., A.A., T.K., Data Collection or Processing: S.A., C.K., M.P., A.A., Analysis or Interpretation: S.A., C.K., M.P., A.A., T.K., Literature Search: S.A., M.P., A.A., Writing: S.A., C.K., T.K.

Conflict of Interest: No conflict of interest was declared by the authors.

Financial Disclosure: This research received no specific grant from any funding agency in the public, commercial, or not-forprofit sectors.

\section{REFERENCES}

1. Wilkerson JD, Brooks DL, Derby M, Griffey SM. Comparison of practical treatment methods to eradicate pinworm (Dentostomella translucida) infections from Mongolian gerbils (Meroines unguiculatus). Contemp Top Lab Anim Sci 2001; 40: 31-6.

2. Hendrix CM. Diagnostic Veterinary Parasitology. Mosby Inc. 2nd edp St. Louis, Mo 1998; 157-9.

3. Zalesyn G, Hildebrand J, Popiotek M, Okulewicz A. Dentostomella translucida Schulz et Krepkorgorskaya, 1932 (Nematoda, Heteroxynematidae), a new species for the European nematofauna. Acta Parasitol 2008; 53: 219-21.

4. Tantelean MV, Quispe M, Angulo JT, Enrique SM. Dentostomella translucida (Nematoda, Oxyuroidea, Heteroxynematodae) in Mesocricetus auratus of Peru. Peru J Parasitol 2011; 19: 73-6.

5. Olude MA, Ajayi OL, Adebayo AO, Akande FA, Ougbagi El. Intestinal intussusception due to concurrent infections with Hymenolepis nana and Dentostomella translucida in an African giant Rat (Cricetomys gambianus). A case report. Sci World J 2010; 5.

6. Pritchett KR, Johnston NA. A review of treatments for the eradication of pinworm infections from laboratory rodent colonies. Contemp Top Lab Anim Sci 2002; 4: 36-46.

7. Burgu A, Alabay $\mathrm{M}$ and Öge H. Gerbilde (Meriones unguiculatus) Dentostomella translucida Schulz ve Krepkorgorskaja, 1932. Vet Fak Dergisi 1992; 39: 291-9.

8. Wightman SR, Pilitt PA, Wagner JE. Dentostomella translucida in the Mongolian gerbil (Meriones unguiculatus). Lab Anim Sci 1978; 28: 290-6. 
9. Kia E, Shahryary-Rad E, Mohebali M, Mahmoudi M, Mobedi I, Zahabiun $\mathrm{F}$, et al. Endoparasites of rodents and their zoonotic importance in germi, dashte-mogan, ardabil province, iran. Iran J Parasitol 2010; 5: 15-20.

10. Ayan A, Pekağırbaş M, Aypak S, Karagenç T. Dentostomella translucida (Gerbil Pinworm) Infection in Mongolian Gerbil (Meriones Unguiculatus) Schulz and Krepkorgorskaja, 1932. Turkiye Parazitol Derg 2018; 42: 2903.

11. Baker DG. Flynn's parasites of laboratory animals. 2th ed. Iowa: Blackwell, 2007; 414-6.

12. Taffs LF. Pinworm infections in laboratory rodents: a review. Lab Anim 1976; 10: 1-13.

13. Şanlı Y, Kaya S. Veteriner farmakoloji ve ilaçla sağaltım seçenekleri. 1 ed. Ankara: Medisan, 1991; 647-60.

14. Kirsch R. In vitro and in vivo studies on the ovicidal activity of fenbendazole. Res Vet Sci 1978; 25: 263-5.

15. Burgu A, Öge S and Gönenç B. Farelerde Aspiculuris tetraptera ve Syphacia obvelata'ya karşı Doramectin ve Ivermectin'in etkisi. Kafkas Univ Vet Fak Derg 1996; 2: 135-8.

16. Gönenç B, Sarimehmetoğlu HO, Iça A, Kozan E. Efficacy of selamectin against mites (Myobia musculi, Mycoptes musculinus and Radfordia ensifera) and nematodes (Aspiculuris tetraptera and Syphacia obvelata) in mice. Lab Anim 2006; 40: 210-3.

17. Şanlı Y. Veteriner klinik farmakoloji ve ilaçla sağaltım ilkeleri. 4th ed. Malatya; Medipres, 2006; 1072-6.

18. MAFF: Manual of veterinary parasitological laboratory techniques reference book, 3th ed Ministry of Agriculture, London, 1986; 159.

19. Panti-May JA, Caraveo-Centeno L, Hernández-Betancourt SF, Robles MDR, Machain-Williams C. Survey of intestinal helminths collected from pet rodents in México. Parasitol Res 2017; 116: 3239-42.

20. Pinto RM, Gomes DC, Menezes RC, Muniz-Pereira LC, Noronha D. First natural helminth infection in the Mongolian gerbil Meriones unguiculatus (Rodentia, Muridae), parasitized with Dentostomella translucida (Nematoda, Heteroxynematidae) in the neotropical region. Braz J Biol 2003; 63: 173-5.

21. Kanchev K, Kamenov Y. First natural helminth infection in the Mongolian gerbil (Meriones unguiculatus) with Dentostomella translucida in Bulgaria. In: Sbornik dokladi ot nauchnata konferentsiya: Traditsii i s'vrenmennost v’v veterinarnata meditsina, Sofia, Bulgaria 2009; 2009: 273-9. 